Entry

\title{
Tissue Integrity and COVID-19
}

\author{
Garry Kerch
}

check for updates

Citation: Kerch, G. Tissue Integrity and COVID-19. Encyclopedia 2021, 1, 206-219. https://doi.org/ 10.3390/encyclopedia1010020

Academic Editor: Antonella Prisco

Received: 7 December 2020

Accepted: 12 February 2021

Published: 14 February 2021

Publisher's Note: MDPI stays neutral with regard to jurisdictional claims in published maps and institutional affiliations.

Copyright: (C) 2021 by the author. Licensee MDPI, Basel, Switzerland. This article is an open access article distributed under the terms and conditions of the Creative Commons Attribution (CC BY) license (https:// creativecommons.org/licenses/by/ $4.0 /)$.
Faculty of Materials Science and Applied Chemistry, Riga Technical University, Riga 1048, Latvia; garrykerch@inbox.lv

Definition: Tissue integrity depends on biological tissue stiffness. Tissue integrity can protect both against age-related diseases and against severity of COVID-19. The disruption of tight junctions and increase of tissue permeability with advancing age can be related with age-related diseases as well as with age-dependent COVID-19. Release of tightly bound water from collagen fibrils leads to the increase of extracellular matrix stiffness and to the associated with matrix stiffness increased tissue permeability. The link between arterial stiffness and oxidative stress has been reported and is expected to be studied in more detail in the future. Trehalose can be suggested for retardation of tightly bound water release and subsequent extracellular matrix crosslinking by advanced glycation end products. Increase in tissue permeability can be blocked by polyphenols that inhibit ICAM-1 expression and mitigate cytoskeleton reorganization. NF- $\mathrm{B}$ B activation as a result of increased stiffness and cytoskeleton reorganization can cause both cardiovascular pathologies and COVID-19. Increased cholesterol content in cell membrane leads to increased virus entry into cell and increase of cholesterol is linked with cardiovascular diseases. Statins and chitosan are known as cholesterol-lowering substances. Nrf2 inhibits NF- $\mathrm{kB}$ activation and NF- $\mathrm{kB}$ inhibits Nrf2 pathway.

Keywords: COVID-19; extracellular matrix; release of bound water; stiffness; NF-кB; Nrf2; polyphenols; chitosan; cholesterol

\section{Introduction}

The pandemic of coronavirus disease 2019 (COVID-19) resulted in an unprecedented crisis in global economy and health-care services. There is no clinically approved antiviral drug available at present to be used in the fight against COVID-19. Much more clear understanding of novel coronavirus behavior is necessary in order to combat it.

Statistical data show that incidence of novel coronavirus SARS-COV-2 and severity of COVID-19 disease were very low in children [1,2], but the chance to become infected and the fatality rate were very high for the older population, especially in patients aged 80 and older $[2,3]$.

Cellular processes depend on the mechanical properties of cellular environment [4] and changes of microenvironment with aging. Development of age-related diseases and age-dependent COVID-19 may be associated with changes in cellular processes as a result of gradual time-dependent biochemical and biophysical changes at molecular level in extracellular matrix, such as collagen crosslinking reactions, dehydration of collagen fibrils with decreasing binding energy between water molecules and functional groups, conformational changes of biological macromolecules. These changes increase stiffness of extracellular matrix with advanced age. Disruption of tissue integrity as a result of extracellulular matrix stiffening and release of tightly bound water molecules from collagen is presented in Figure 1. 


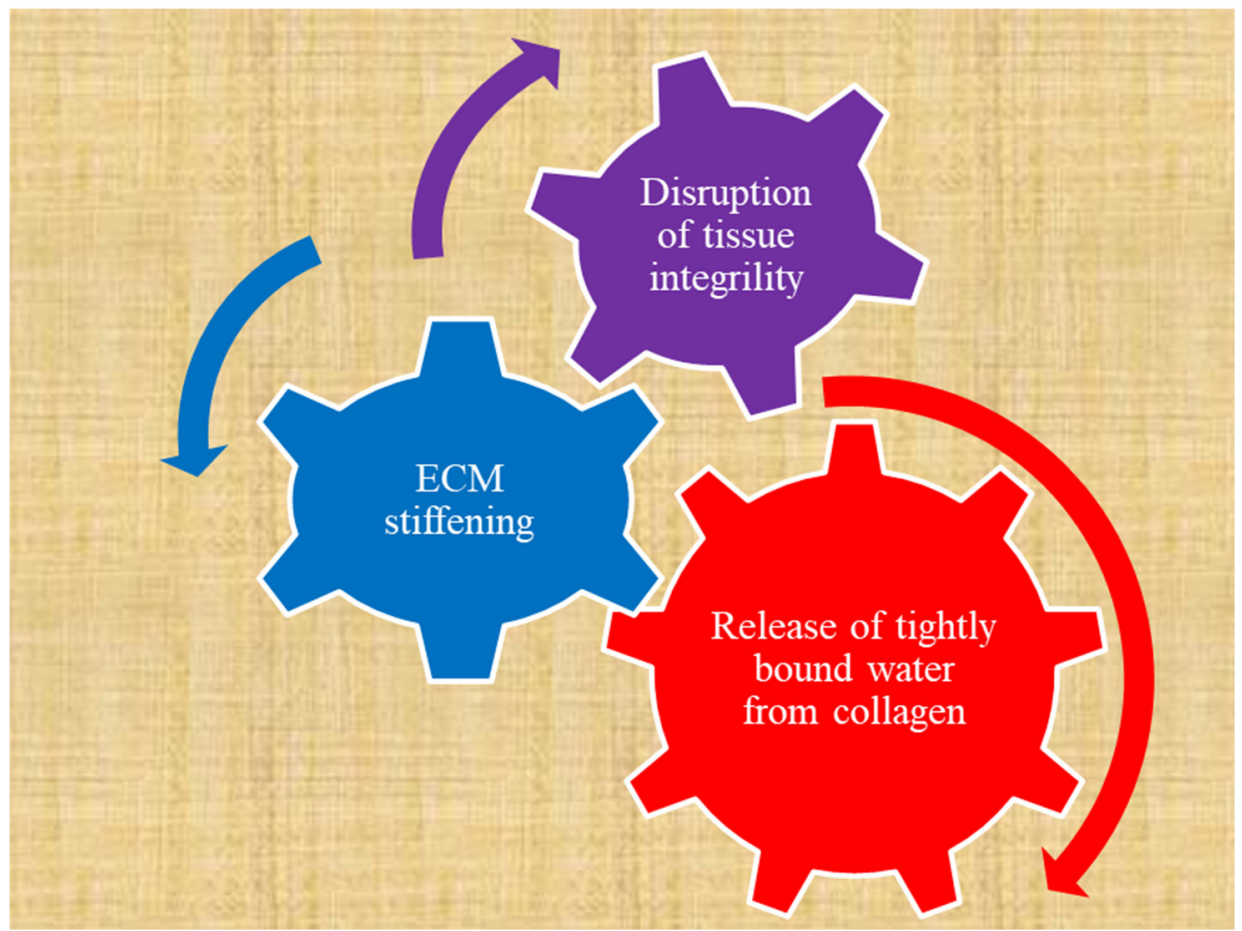

Figure 1. Release of tightly bound water from collagen fibrils increases biological tissue permeability as a result of increase in extracellular matrix (ECM) stiffness.

The aim of this entry is to discuss the potential of results based on mechanobiology of biomaterials to be used in the possible translation of emerging destiffening therapies from cardiology to the treatment of COVID-19 patients by repurposing already existing drugs.

Influence of age-related changes on incidence and severity of COVID-19 mentioned in the introduction is evident. Strong age dependence on disease severity may be related with commonly known increasing of tissue stiffness, and more specifically arterial stiffness, with advanced age. Cells are mechanosensitive and respond to the stiffness of their environment [5]. Immune cells are also mechanosensitive. The interaction and mutual relationship between immune cells and endothelial cells, vascular smooth muscle cells, platelets, and monocytes/macrophages were demonstrated [6]. So, the close link between decline in immune system with aging and arterial stiffening with advanced age can be suggested. Gradual release of tightly bound water molecules from collagen fibrils can be considered as a process driven by entropy. The change of water state from tightly bound to loosely bound and free water results in increase of entropy of a system. Water acts as a tissue plasticizer and loss of water leads to increase of tissue stiffness and disruption of tight junctions and decreased integrity, Figure 1. Extracellular matrix (ECM) stiffening in Figure 1 may be replaced by immune system response decline because age-associated changes in the immune system are closely related with tissue integrity and barrier functions. There is a link between immune system function and ECM stiffness due to immune cells mechanosensitivity.

Exercise in a hot environment may be considered as a combination of mechanical forces and loss of water. The effect of exercise on circulating immune cell responses and immune cell function has been reported by researchers at Exercise Physiology Laboratory of Texas Christian University [7]. They found that exercise affects immune system and that the number of leukocytes, neutrophils, lymphocytes, and natural killer cells were higher as a result of exercise. It has been also demonstrated that dehydration is closely related with oxidative stress [8]. Evidently oxidative damage leads to disruption of tissue integrity and to the increase of tissue permeability. 
It has been reported that platelet adhesion is higher on rigid chitosan coatings containing tightly bound water molecules if compared with softer chitosan coatings containing water molecules with lower binding energy to biological macromolecules [9].

\section{Tissue Integrity Factors Involved in COVID-19 Treatment}

\subsection{Aging, Dehydration, Glycation, and Stiffness}

Evidently, host tissue stiffness and permeability play important roles in novel coronavirus SARS-COV-2 entry into cells. Children have a high content of tightly bound water in organism that gradually decreases with advanced age. Dehydration results in increase of tissue stiffness [10-12] and can be linked with glycation processes and accumulation of glycation end products [13]. This means that dehydration and glycation processes, as well as bound water release and transformation into loosely bound and free water, play important roles both in age-related pathologies, such as cardiovascular diseases, diabetes, cancer, and obesity due to increased stiffness and, very likely, in COVID-19. Increased stiffness has been related with increased tissue permeability as a result of tight junction disruption. Increase of extracellular matrix stiffness leads to F-actin polymerization regulated by small GTPase RhoA and stress fibers formation. Inhibition of RhoA/ROCK decreases stress fibers formation. Stiff extracellular matrices increase RhoA-mediated actomyosin contractility that occurs with aging. Increased actomyosin contractility leads to the disruption of cell-cell junctions and increased permeability. Cell-cell junction width in aorta from old mice was higher if compared with cell-cell junction width in aorta from young mice. Increase in endothelial permeability leads to the increased leukocyte extravasation and thrombus formation. Rho-dependent cell contractility is responsible for increased stiffness and it was shown that using Y-27632, an inhibitor of Rho-associated kinase, it is possible to decrease permeability in vitro and in vivo [14]. It has been recently reported that Rho kinase inhibitor decreases inflammation, immune cell migration, apoptosis, and cell adhesion in pulmonary endothelial cells in the treatment of acute lung injury [15]. Elevated expression of adhesion molecules vascular cell adhesion molecule-1 (VCAM-1), intercellular adhesion molecule 1 (ICAM-1), and vascular adhesion protein-1 (VAP-1) was reported in COVID-19 patients [16]. Plasma levels of interleukin (IL)-1 $\beta$, tumor necrosis factor (TNF)- $\alpha$, and interleukin (IL)-6 have been found to be higher in patients with mean carotid-femoral pulse wave velocity (PWV) $>8 \mathrm{~m} / \mathrm{s}$ compared with patients having PWV $<8 \mathrm{~m} / \mathrm{s}$ [17]. Blakney and coauthors demonstrated that IL-6 production increases on rigid substrates. Macrophages increased expression of associated with inflammation tumor necrosis factor- $\alpha$ (TNF- $\alpha$ ), interleukin-1 $\beta$ (IL-1 $\beta$ ), interleukin-6 (IL-6) was observed on stiffer hydrogels [18]. Macrophage behavior depends on substrate stiffness. The anti-inflammatory property of macrophages on soft and medium gels is ROCK-dependent. Stiff gels were associated with proinflammatory property of macrophages and decreased migration and phagocytosis [19]. Commonly, tissue density transforms with aging from loose to dense tissue and tissue density can be related with macrophage activation. It has been found that secretion of cytokines in 3D collagen matrices is increased with an increase of collagen fibril density. This means that macrophage activation state, phenotype, and functions are different in different tissues. Macrophage phenotype can be proinflammatory or anti-inflammatory depending on microenvironmental cues [20]. Mechanoimmunology is emerging science still in its infancy and further studies on molecular-scale mechanical forces are needed to discover precise mechanobiological mechanisms that govern immune responses to changes in living biological tissue mechanical properties [21].

So, it can be expected that tissue stiffness and inflammation can play important roles also in COVID-19. This suggests that therapeutic approaches to overcome the COVID-19 can focus on drugs similar to those used in the treatment of above-mentioned age-related diseases.

There is an urgent need for finding safe drugs for treatment of COVID-19. Uhler and Shivashankar [22] in the recent publication linked replication of coronaviruses with the influenced by ageing cytoskeleton-dependent signaling and 3D genome organization. 
They considered that cytoskeleton-dependent NF- $\mathrm{KB}$ pathway can control viral replication. Gene expression programs depend on the mechanical state of cells. NF- $\mathrm{kB}$ and mechanotransduction pathways are considered as possible therapeutic targets. It is important to understand that mechanical states have essential influence on cellular processes and on coronavirus function. So, if signaling pathways are already activated and result in any of age-related diseases, the pathogenicity of coronavirus will be higher as it was already observed in clinical practice.

Tissue stiffness depends on binding energy of water molecules to biological macromolecules and release of tightly bound water as a plasticizer leads to the increase of tissue stiffness, tissue permeability, and to development of age-related diseases and agedependent COVID-19, Figure 2.

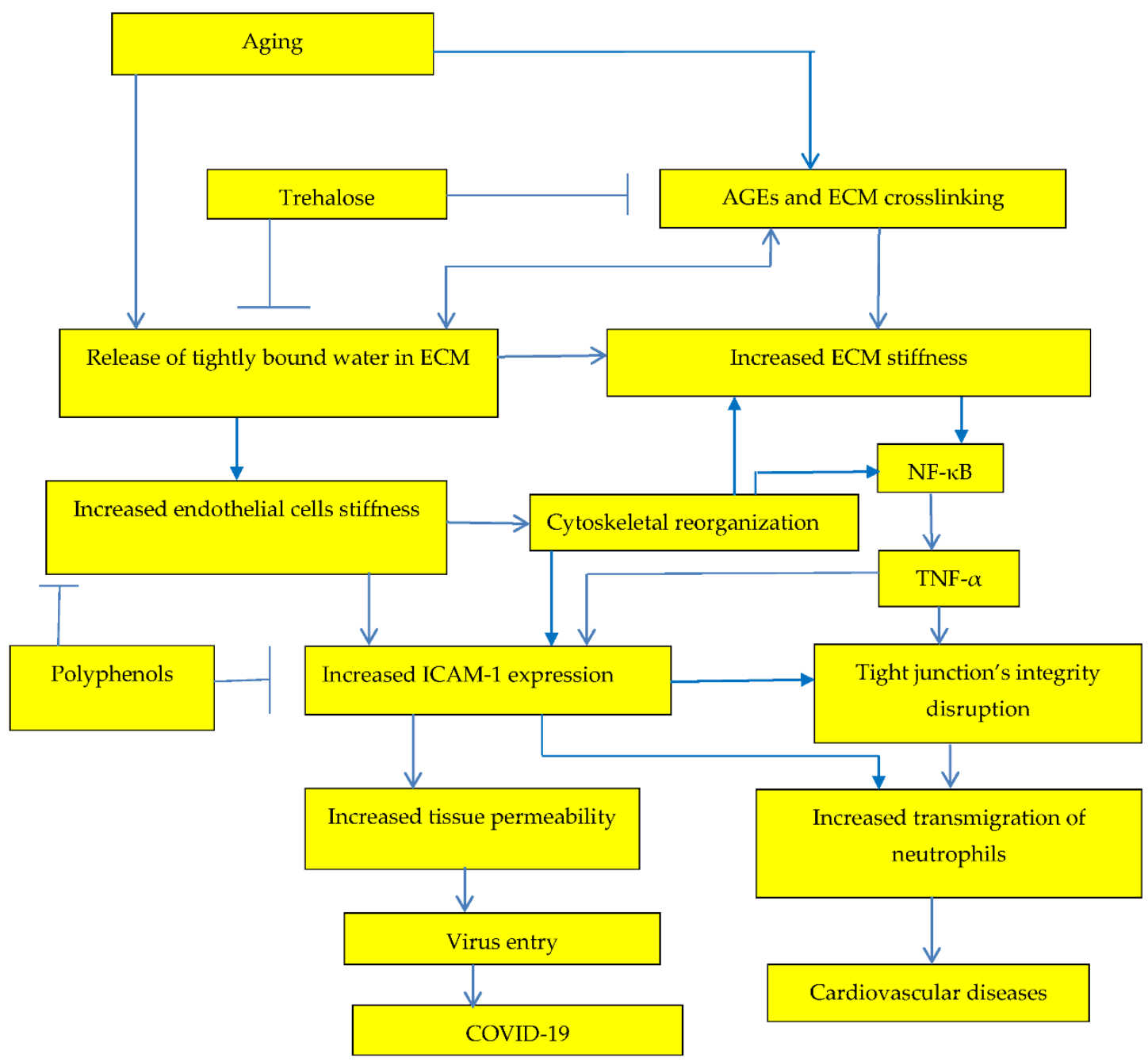

Figure 2. Increase of extracellular matrix stiffness results both in increased risk of age-related cardiovascular disease and in increased risk of COVID-19.

\subsection{Inflammation and Arterial Stiffness}

It has been concluded that inflammation plays an important role in the development of arterial stiffness. The interplay between arterial stiffness and inflammation is evident $[23,24]$. Arterial stiffness leads to development of inflammation mainly due to cells mechanosensing, for example neutrophils, that play an important role in immune response, migrate more slowly on stiffer substrates because of higher adhesion but they migrate on higher distances [25]. Inflammation increases due to increased arterial stiffness rather than arterial stiffness increases due to inflammation, Figure 3. 


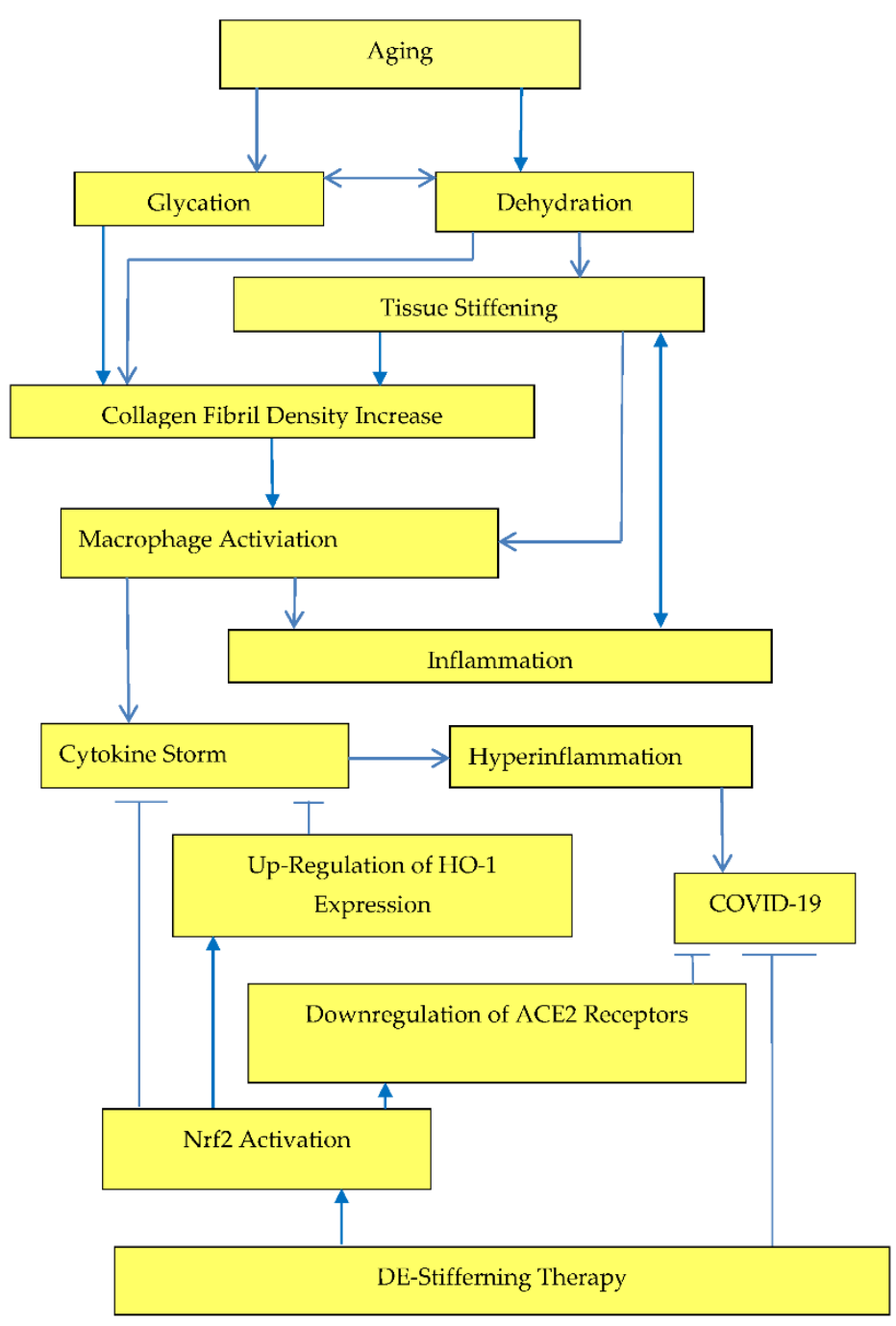

Figure 3. Crosstalk between tissue stiffness and inflammation.

High-sensitivity C-reactive protein (hs-CRP) levels have been associated with increased aortic stiffness [26-28]. High-sensitivity C-reactive protein (hs-CRP) is a marker of chronic low-grade inflammation. A number of drugs that reduce C-reactive protein levels have been reviewed by Prasad [29]. It has been reported that $C$-reactive protein was upregulated in patients with severe COVID-19 $[30,31]$. So, the drugs that reduce C-reactive protein levels can be tested in the treatment of COVID-19 patients.

\subsection{Expression of Cytokines}

Dehydration and increased with aging tissue stiffness initiates actomyosin contractions, which triggers NF- $\mathrm{kB}$ activation, Figure 2. NF- $\mathrm{kB}$ activation was related with various age-related diseases and overproduction of proinflammatory cytokines (TNF- $\alpha$ and IL-6). Activation of Nrf2 prevents transcriptional upregulation of proinflammatory cytokines [32] and Nrf2-dependent gene HO-1 expression suppresses TNF- $\alpha$-stimulated NF-kB and inhibits vascular cell adhesion molecule-1 expression [33], Figure 3.

The various methods to prevent or decrease cytokine storm in COVID-19 patients have been recently reviewed [34]. The application of interleukin-1 blockers, interleukin6 inhibitors, and Janus kinase inhibitors in treatment of COVID-19 has been suggested with the aim to block hyperinflammation [35]. The therapy by the anti-IL-6 receptor antibody tocilizumab results in the decrease of arterial stiffness determined by pulse wave velocity [36]. So, tocilizumab may be considered also as a destiffening drug with a potential to improve biological tissue integrity. Tocilizumab has been suggested as 
additional treatment for COVID-19 patients with the aim to decrease a risk of cytokine storm by reducing C-reactive protein (CRP) and IL-6 content [37].

Effectiveness of canakinumab has been suggested [38]. Canakinumab is a human anti-IL-1 $\beta$ monoclonal antibody developed by Novartis and at the end of 2020 it has been announced that canakinumab failed to improve survival in COVID-19 [39]. According to European Medical Agency report canakinumab did not change aortic stiffness [40]. However, improvement both in cardiovascular diseases and in COVID-19 can be achieved by the decrease of extracellular matrix stiffness, Figure 2.

Clinical efficacy of anakinra in severely ill COVID-19 patients has been suggested. Decrease of hyperinflammation as a result of treatment with anakinra was recently reported [41]. Anakinra inhibits both IL- $1 \alpha$ and IL-1 $\beta$. It has been found that mice that lack autophagy gene in macrophages, developed significantly more severe acute lung with increased lung permeability and higher IL-1 $\beta$ production in the alveolar space. Autophagy prevents the development of increased lung permeability by suppressing IL-1 $\beta$ [42]. It has been also recently reported that substrate stiffness essentially impacts autophagy [43]. So, it is possible to suggest that changes in microenvironment stiffness can prevent the increase in lung permeability.

Advanced age and severity of COVID-19 are the risk factors for the development of post COVID-19 pulmonary fibrosis. This means that increased extracellular matrix stiffness and tissue permeability can be associated with lung fibrosis development during COVID-19 and after the discharge from hospital. Cytokine storm with IL- 6 and TNF $\alpha$ involved in the process may initiate pulmonary fibrosis development. Antifibrotic drugs, such as pirfenidone and nintedanib, have been recommended for the use in the treatment of post COVID-19 pulmonary fibrosis [44].

Tissue stiffness plays an important role in fibrosis initiation and development $[45,46]$. It has been suggested that increase in liver stiffness plays an important role in initiation of the early stages of fibrosis [47].

It has been reported that transcriptional effectors of the Hippo pathway yes-associated protein (YAP) and transcriptional coactivator with PDZ-binding motif (TAZ) are expressed in fibrotic lung tissue and depending on matrix stiffness coordinate fibroblast activation and matrix synthesis. Both YAP and TAZ translocate into the nuclei of fibroblasts only if they are cultured on pathologically stiff matrices. Active YAP and TAZ are fibrogenic and drive the development of fibrosis in the lung [48].

Increased extracellular matrix stiffness inhibits expression of COX-2 (cyclooxygenase2) and limits synthesis of antifibrotic prostaglandin E(2) (PGE2) [49]. Increased matrix stiffness leads to fibroblast activation and collagen secretion [50,51] and soft matrix can reverse fibroblast activation in idiopathic pulmonary fibrosis [52].

Researchers at Lund University, Sweden, linked pulmonary fibrosis development with COVID-19 severity [53]. Pulmonary fibrosis was associated with the increased expression of angiotensin converting enzyme 2 (ACE2) in risk groups with increased tissue stiffness in patients with advanced age [54], obesity [55], and cardiovascular diseases [56]. So increased ACE2 expression can be linked with increased matrix stiffness. ACE2 are functional receptors for SARS-CoV-2. SARS-CoV-2 activates fibrosis-related genes and increased production of ACE2 that drives lung fibrosis [57,58].

In COVID-19 patients requiring mechanical ventilation, ACE2 expression in lung increases with age and did not change with age for nonventilated patients [59].

However, age-dependent decrease of ACE2 also has been reported and negative correlation between ACE2 expression and COVID-19 fatality has been suggested [60]. Biological tissue permeability also increases with aging. Researchers at Shanghai Jiaotong University, China, reported that acute lung injury (ALI) increased lung vessel permeability, but ACE2 alleviated the ALI-induced increases in lung vessel permeability and suppresses the severity of ALI [61]. ACE2 levels can be associated with pulmonary vascular permeability. Low levels of ACE2 may result in increased levels of angiotensin II (AngII) which leads 
to inflammation, fibrosis, and oxidative stress during infection with SARS-CoV-2 [62]. Angiotensin receptor antagonists decrease arterial stiffness [63].

\subsection{Polyphenols}

It has been shown [64] that green tea polyphenols, such as (-)-epigallocatechin gallate (EGCG), regulate tight junctions reducing blood-brain barrier (BBB) permeability during experimental focal cerebral ischemia in animal experiments with male Wistar rats. Flavonoids genistein, quercetin, myricetin, and EGCG improve intestinal tight junction barrier function [65]. Impairment of the intercellular tight junction is associated with various age-related diseases. Intestinal permeability is elevated in the older population [66]. The effect of polyphenols on intestinal permeability has been recently reviewed $[2,67]$. Polyphenols suppress ICAM-1 expression [16], Figure 2, and increase tissue integrity. Cytoskeleton reorganization leads to the NF- $\mathrm{KB}$ activation [67] and to the increase of tissue stiffness, Figure 2. It has been also suggested that the ability of vitamin $D$ to maintain tight junctions can decrease the incidence, severity, and risk of death from influenza, pneumonia, and the COVID-19 pandemic [68]. It has been suggested that flavonoid supplements combined with vitamin D3 can activate transcription factor Nrf2, and decrease SARS-CoV-2 infection severity, reducing oxidative stress and downregulating ACE2 receptors [69]. Downregulation of ACE2 receptors by phytochemical composition PB125 has been also suggested [70]. Vitamin D decreases aortic stiffness. At the same time, it has been demonstrated that vitamin D supplementation could reduce risk of influenza and COVID-19 infections and deaths $[2,68]$.

\subsection{Nrf2-Keap1 Pathway}

Nrf2-Keap1 pathway regulates tight junction proteins in intestinal barrier by suppressing the NF- $\mathrm{KB}$ pathway and decreasing reactive oxygen species generation. Nrf2 translocation into the nucleus activates antioxidant and cytoprotective gene expression [71]. Nrf2 can be activated by anthocyanins [72], sulforaphane [73], PB125 synergistic combination of phytochemical extracts of Rosmarinus officinalis, Withania somnifera, and Sophora japonica $[70,74]$ and by curcumin $[75,76]$. Expression of Nrf2 and its downstream genes was upregulated in chondrocytes treated with hyaluronic acid [77]. Nrf2-dependent antiinflammatory drugs from plant extracts have been reviewed [78].

\subsection{NF- $\kappa B$ Activation}

COVID-19 can be considered as an age-dependent disease. So, the role of NF- $\mathrm{kB}$ activation in development of COVID-19 disease must be investigated and the potential effectiveness of NF- $\mathrm{KB}$ pathway inhibitors in the treatment of COVID-19 disease must be estimated. Downregulation of NF- $\mathrm{kB}$, as a pathway involved in the inflammation process, by polyphenols was suggested $[67,79]$. Increased survival of coronavirus infected mice as a result of inhibition of NF-KB mediated inflammation was reported [80]. It has been recently reported [81] that $\mathrm{N}$-acetyl-cysteine, alpha-lipoic acid, and glutathione inhibit TNF- $\alpha$-induced NF- $\mathrm{KB}$ activation. Blocking NF- $\mathrm{KB}$ decreases cytokine storm syndrome in patients suffering with COVID 19 pneumonia. Zinc and vitamin $C$ may also lower cytokine production.

In a number of publications, a link between elevated serum levels of TNF- $\alpha$ and NF- $\kappa B$ activation and increased vascular stiffness has been demonstrated [82-89]. Intestinal permeability also increases with aging under elevated serum levels of TNF- $\alpha$. Anti-TNF- $\alpha$ therapy can reverse negative changes [90]. It has been recently reported that disrupted gut barrier integrity is responsible for COVID-19 severity [91]. NF- $\mathrm{KB}$ and Nrf2 play functionally opposing roles in the pathological processes. It has been reported that in the cells where NF- KB and Nrf2 were simultaneously activated NF-KB p65 subunit suppressed the transcriptional activity of Nrf2 decreasing the expression of anti-inflammatory or antitumor genes [92]. Activation of Nrf2 can also suppress NF- $\mathrm{kB}$-mediated inflammatory processes in COVID-19 [92], Figure 4. Application of sulforaphane, as inducer of Nrf2, has been 
suggested for treatment of COVID-19 [93]. Nrf2 activation in peritoneal macrophages decreases the production of COX-2 (cyclooxygenase 2), TNF $\alpha$, iNOS (inducible nitric oxide synthase), and IL- $1 \beta$ in response to lipopolysaccharides [94,95]. Human adipose-derived mesenchymal stem cells on mechanically tunable fibronectin-conjugated polyacrylamide (FN-PAAm) hydrogel substrates have been studied and it has been found that the intranuclear Nrf2 level of the cells grown on the soft $0.15 \mathrm{kPa}$ FN-PAAm hydrogel was about three times higher compared with intranuclear Nrf2 level in the cells cultured on the hard glass surfaces. Upregulation of downstream target of Nrf2 heme oxygenase-1 was also reported [96]. So, the decrease in substrate stiffness activated Nrf2.

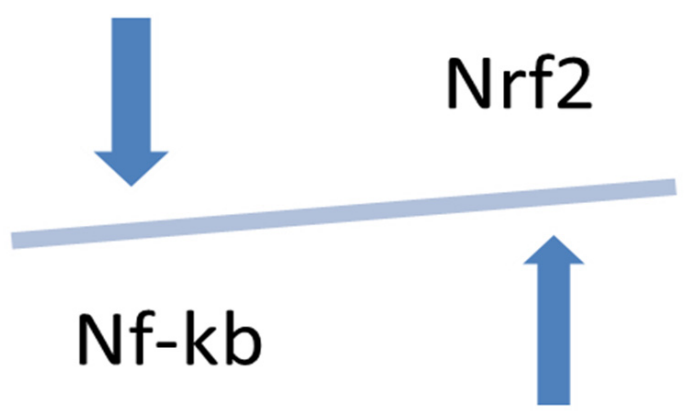

Figure 4. Opposing effects of transcriptional factors NF- $\mathrm{KB}$ and Nrf2 on arterial stiffness and inflammation.

\subsection{Obesity}

Intestinal permeability is elevated in obese subjects. Zonulin level, a potential marker of interstitial permeability, positively correlated with age, body mass, fat mass, and fat percentage [97]. Obesity increases extracellular matrix stiffness and enhances breast cancer risk. Adipose stromal cells isolated from obese mice deposited denser and stiffer extracellular matrix if compared with adipose stromal cells from lean control mice [98]. Obesity was associated with arterial stiffness [55]. Severity of COVID-19 is also higher in obese subjects.

Similarly, to the link between obesity and malignancy, the link between obesity and COVID 19 may be expected.

\subsection{Trehalose}

Trehalose, a nonreducing disaccharide, has been generally recognized as safe (GRAS) status. Trehalose has been proposed by researchers at Cedars-Sinai Medical Center, Los Angeles, USA for COVID-19 containment [99]. It was discovered in 2007 by researchers at Addenbrooke's Hospital, University of Cambridge, United Kingdom that trehalose is an autophagy activator [100]. It has been reported in 2009 that trehalose inhibits inflammatory cytokines interleukin-1 $\beta$ (IL- $1 \beta$ ) and tumor necrosis factor- $\alpha$ (TNF- $\alpha$ ) production [101].Trehalose has been suggested to be used in diabetes management [102]. Trehalose demonstrated anti-inflammatory and antioxidant effects [103]. Trehalose can inhibit release of tightly bound water in extracellular matrix (ECM) preventing increase of ECM stiffness and related increase in production of inflammatory cytokines, Figure 2.

\subsection{Cholesterol}

Decrease in extracellular matrix stiffness and related Nrf2 activation results in upregulation of heme oxygenase-1(HO-1) expression, Figure 3. The potential of $\mathrm{HO}-1$ in the fight against COVID-19 has been described by Hooper [104]. He suggested that heme oxygenase level can be increased by HO-1 inducers such as cholesterol-lowering medications statins, curcumin, resveratrol, melatonin, hemin, and estrogen.

Low HO-1 content or higher tissue permeability due to higher extracellular matrix stiffness in the older population can be related with higher incidence and severity of COVID-19 disease [2,104]. It has been demonstrated that cholesterol increases binding of SARS-CoV-2 to the cell surface. High cholesterol level in lipid rafts on the plasma 
membrane containing angiotensin-converting enzyme 2 (ACE2) receptors for the spike protein of coronaviruses plays an important role in the coronavirus entry processes [105,106]. Cholesterol level in tissue increases with aging. High content of cholesterol can be linked with high arterial stiffness. Obesity was associated with increased arterial stiffness and elevated cholesterol and C-peptide levels [107]. Statins can decrease content of cholesterol in the membranes of cells, and reduced content of cholesterol can prevent viruses from entering cells $[108,109]$. Researchers at University of California San Diego, USA suggested that depletion of cell membrane cholesterol blocks SARS-CoV-2 entry and decreased severity of COVID 19 [109]. It has been also suggested that simvastatin can reduce matrix stiffness [110]. Antiviral activities of statins against influenza have been already discussed and decrease of proinflammatory cytokines TNF- $\alpha$ and IL- 6 by simvastatin and atorvastatin was reported [111,112]. Evidently now is the time for experimental and clinical confirmation of statins applicability in COVID-19 treatment [111]. It is well known that chitosan also can decrease the content of cholesterol [113]. Chitosan prevents cholesterol deposition into erythrocyte membranes [114]. So, chitosan derivatives can be investigated with the aim to find the best structural parameters and prepare chitosan to be used in prevention of SARS-COV-2 virus entry into host cells. However, it must be always taken into account that glycation reactions can take place in the presence of chitosan [115].

\section{Conclusions and Prospects}

Changes in immune system response with aging can be closely related with increased tissue stiffening and disruption of tight junctions.

Incidence and severity of COVID-19 depends on patient's biological tissue quality. High resistance in children and high incidence and severity in elderly was observed.

Biological tissue function, structure, and quality change with advanced age as a result of extracellular matrix stiffening. Tissue stiffening can be explained by transformation of tightly bound water into loosely bound and free water and by density changes in collagen fibrils due to local release of water. Disruption of tight junctions in extracellular matrix leads to reduction of tissue integrity and increased cell membrane permeability. Such age-related processes change vulnerability to COVID-19, its incidence, and severity with aging. Decrease in tissue integrity can be observed both in the aging processes and in COVID-19. So, a more specific treatment of COVID-19 must be developed and provided for the older population in the future.

Mechanosensing plays an important role in the development of age-related diseases, such as hypertension, diabetes, cardiovascular diseases, obesity, neurologic diseases, and cancer as well as in the development of age-dependent COVID-19.

TNF- $\alpha$ antagonists possess a beneficial effect on aortic stiffness and extracellular matrix integrity and have potential to protect the elderly population both from age-related diseases and from COVID-19.

The potential application of destiffening therapies for treatment of COVID-19 and age-related diseases must be estimated.

Oxidative stress is related with tissue dehydration. Release of tightly bound water molecules from collagen fibrils causes disruption in tissue integrity. Dehydration can result in accumulation of reactive oxygen species and increase of oxidative stress.

Trehalose has potential to be used in COVID-19 prophylaxis and treatment due to its autophagy-dependent antiviral activities and inhibition of tightly bound water release in ECM.

Inhibition of TNF- $\alpha$-induced NF- $\mathrm{KB}$ activation decreases cytokine storm in patients suffering with COVID 19. NF-kB inhibitors and Nrf2 activators have been suggested for COVID 19 treatment.

Funding: This research received no external funding.

Conflicts of Interest: The author declares no conflict of interest.

Entry Link on the Encyclopedia Platform: https:/ / encyclopedia.pub/8077. 


\section{References}

1. Wu, Z.; McGoogan, J.M. Characteristics of and Important Lessons from the Coronavirus Disease 2019 (COVID-19) Outbreak in China: Summary of a Report of 72314 Cases from the Chinese Center for Disease Control and Prevention. JAMA 2020, 323, 1239-1242. [CrossRef]

2. Kerch, G. Role of changes in state of bound water and tissue stiffness in development of age-related diseases. Polymers (Basel) 2020, 12, 1362. [CrossRef]

3. Bonanad, C.; García-Blas, S.; Tarazona-Santabalbina, F.; Sanchis, J.; Bertomeu-González, V.; Fácila, L.; Ariza, A.; Núñez, J.; Cordero, A. The Effect of Age on Mortality in Patients With COVID-19: A Meta-Analysis With 611,583 Subjects. J. Am. Med. Dir. Assoc. 2020, 21, 915-918. [CrossRef]

4. Baumann, K. Environment dictates behaviour. Nat. Rev. Mol. Cell Biol. 2010, 11, 679. [CrossRef]

5. Janmey, P.A.; Fletcher, D.A.; Reinhart-King, C.A. Stiffness sensing by cells. Physiol. Rev. 2020, 100, 695-724. [CrossRef] [PubMed]

6. Lacolley, P.; Regnault, V.; Avolio, A.P. Smooth muscle cell and arterial aging: Basic and clinical aspects. Cardiovasc. Res. 2018, 114, 513-528. [CrossRef] [PubMed]

7. Mitchell, J.B.; Dugas, J.P.; McFarlin, B.K.; Nelson, M.J. Effect of exercise, heat stress, and hydration on immune cell number and function. Med. Sci. Sports Exerc. 2002, 34, 1941-1950. [CrossRef] [PubMed]

8. Jacobs, P.J.; Oosthuizen, M.K.; Mitchell, C.; Blount, J.D.; Bennett, N.C. Heat and dehydration induced oxidative damage and antioxidant defenses following incubator heat stress and a simulated heat wave in wild caught four-striped field mice Rhabdomys dilectus. PLoS ONE 2020, 15, e0242279. [CrossRef]

9. Kerch, G.; Zicans, J.; Merijs Meri, R.; Stunda-Ramava, A.; Jakobsons, E. The use of thermal analysis in assessing the effect of bound water content and substrate rigidity on prevention of platelet adhesion. J. Therm. Anal. Calorim. 2015, 120, 533-539. [CrossRef]

10. Kerch, G. Polymer hydration and stiffness at biointerfaces and related cellular processes. Nanomed. Nanotechnol. Biol. Med. 2018, 14, 13-25. [CrossRef]

11. Kerch, G. Distribution of tightly and loosely bound water in biological macromolecules and age-related diseases. Int. J. Biol. Macromol. 2018, 118, 1310-1318. [CrossRef]

12. Shahmirzadi, D.; Bruck, H.A.; Hsieh, A.H. Measurement of Mechanical Properties of Soft Tissues In Vitro Under Controlled Tissue Hydration. Exp. Mech. 2013, 53, 405-414. [CrossRef]

13. Bridelli, M.G.; Stani, C.; Bedotti, R. Fourier transform infrared conformational investigation of type I collagen aged by in vitro induced dehydration and non-enzymatic glycation treatments. J. Biol Res. 2017, 90, 45-50. [CrossRef]

14. Huynh, J.; Nishimura, N.; Rana, K.; Peloquin, J.M.; Califano, J.P.; Montague, C.R.; King, M.R.; Schaffer, C.B.; Reinhart-King, C.A. Age-related intimal stiffening enhances endothelial permeability and leukocyte transmigration. Sci. Transl. Med. 2011, 3, 112-122. [CrossRef] [PubMed]

15. Abedi, F.; Hayes, A.W.; Reiter, R.; Karimi, G. Acute Lung Injury: The therapeutic role of Rho kinase inhibitors. Pharm. Res. 2020, 155, 104736. [CrossRef] [PubMed]

16. Tong, M.; Jiang, Y.; Xia, D.; Xiong, Y.; Zheng, Q.; Chen, F.; Zou, L.; Xiao, W.; Zhu, Y. Elevated Serum Endothelial Cell Adhesion Molecules Expression in COVID-19 Patients. J. Infect. Dis. 2020, 222, 894-898. [CrossRef]

17. Tuttolomondo, A.; Pecoraro, R.; Buttà, C.; Di Raimondo, D.; Ferrante, A.; Della Corte, V.; Ciccia, F.; Bellia, C.; Giardina, A.; Raffa, A.; et al. Arterial stiffness indexes and serum cytokine levels in seronegative spondyloarthritis: Relationships between stiffness markers and metabolic and immunoinflammatory variables. Scand. J. Rheumatol. 2015, 44, 474-479. [CrossRef]

18. Blakney, A.K.; Swartzlander, M.D.; Bryant, S.J. The effects of substrate stiffness on the in vitro activation of macrophages and in vivo host response to poly(ethylene glycol)-based hydrogels. J. Biomed. Mater. Res. A 2012, 100, 1375-1386. [CrossRef] [PubMed]

19. Sridharan, R.; Cavanagh, B.; Cameron, A.R.; Kelly, D.J.; O’Brien, F.J. Material stiffness influences the polarization state, function and migration mode of macrophages. Acta Biomater. 2019, 89, 47-59. [CrossRef] [PubMed]

20. Sapudom, J.; Mohamed, W.K.E.; Garcia-Sabaté, A.; Alatoom, A.; Karaman, S.; Mahtani, N.; Teo, J.C.M. Collagen Fibril Density Modulates Macrophage Activation and Cellular Functions during Tissue Repair. Bioengineering 2020, 7, 33. [CrossRef]

21. Pageon, S.V.; Govendir, M.A.; Kempe, D.; Biro, M. Mechanoimmunology: Molecular-scale forces govern immune cell functions. Mol. Biol. Cell 2018, 29, 1919-1926. [CrossRef]

22. Uhler, C.; Shivashankar, G.V. Mechano-genomic regulation of coronaviruses and its interplay with ageing. Nat. Rev. Mol. Cell Biol. 2020, 21, 247-248. [CrossRef]

23. Mozos, I.; Malainer, C.; Horbańczuk, J.; Gug, C.; Stoian, D.; Luca, C.T.; Atanasov, A.G. Inflammatory Markers for Arterial Stiffness in Cardiovascular Diseases. Front. Immunol. 2017, 8, 1058. [CrossRef]

24. Ayhan, H.; Kasapkara, H.A.; Aslan, A.N.; Durmaz, T.; Keleş, T.; Akçay, M.; Bayram, N.A.; Baştuğ, S.; Bilen, E.; Sarı, C.; et al. Relationship of Neutrophil-to-Lymphocyte Ratio with Aortic Stiffness in Type 1 Diabetes Mellitus. Can. J. Diabetes 2015, 39, 317-321. [CrossRef]

25. Oakes, P.W.; Patel, D.C.; Morin, N.A.; Zitterbart, D.P.; Fabry, B.; Reichner, J.S.; Jay, X.; Tang, J.X. Neutrophil morphology and migration are affected by substrate elasticity. Blood 2009, 114, 1387-1395. [CrossRef] [PubMed]

26. Nakhai-Pour, H.; Grobbee, D.; Bots, M.; Muller, M.; van der Schouw, Y.T. C-reactive protein and aortic stiffness and wave reflection in middle-aged and elderly men from the community. J. Hum. Hypertens. 2007, 21, 949-955. [CrossRef] [PubMed] 
27. Kullo, I.J.; Seward, J.B.; Bailey, K.R.; Bielak, L.F.; Grossardt, B.R.; Sheedy, P.F.; Peyser, P.A.; Turner, S.T. C-reactive protein is related to arterial wave reflection and stiffness in asymptomatic subjects from the community. Am. J. Hypertens. 2005, 18, 1123-1129. [CrossRef] [PubMed]

28. Kampus, P.; Kals, J.; Ristimae, T.; Fischer, K.; Zilmer, M.; Teesalu, R. High-sensitivity C-reactive protein affects central haemodynamics and augmentation index in apparently healthy persons. J. Hypertens. 2004, 22, 1133-1139. [CrossRef] [PubMed]

29. Prasad, K. C-Reactive Protein (CRP)-Lowering Agents. Cardiovasc. Drug Rev. 2006, 24, 33-50. [CrossRef]

30. Tan, M.; Liu, Y.; Zhou, R.; Deng, X.; Li, F.; Liang, K.; Shi, Y. Immunopathological characteristics of coronavirus disease 2019 cases in Guangzhou, China. Immunology 2020, 160, 261-268. [CrossRef]

31. Wang, L. C-reactive protein levels in the early stage of COVID-19. Med. Mal. Infect. 2020, 50, 332-334. [CrossRef] [PubMed]

32. Kobayashi, E.H.; Suzuki, T.; Funayama, R.; Nagashima, T.; Hayashi, M.; Sekine, H.; Tanaka, N.; Moriguchi, T.; Motohashi, H.; Nakayama, K.; et al. Nrf2 suppresses macrophage inflammatory response by blocking proinflammatory cytokine transcription. Nat. Commun. 2016, 7, 11624. [CrossRef] [PubMed]

33. Pae, H.O.; Oh, G.S.; Lee, B.S.; Rim, J.S.; Kim, Y.M.; Chung, H.T. 3-Hydroxyanthranilic acid, one of L-tryptophan metabolites, inhibits monocyte chemoattractant protein-1 secretion and vascular cell adhesion molecule-1 expression via heme oxygenase-1 induction in human umbilical vein endothelial cells. Atherosclerosis 2006, 187, 274-284. [CrossRef]

34. Tang, L.; Yin, Z.; Hu, Y.; Mei, H. Controlling cytokine storm is vital in COVID-19. Front. Immunol. 2020, 11, 570993. [CrossRef] [PubMed]

35. Ucciferri, C.; Vecchiet, J.; Falasca, K. Role of monoclonal antibody drugs in the treatment of COVID-19. World J. Clin. Cases 2020, 8 , 4280-4285. [CrossRef]

36. Protogerou, A.D.; Zampeli, E.; Fragiadaki, K.; Stamatelopoulos, K.; Papamichael, C.; Sfikakis, P.P. A pilot study of endothelial dysfunction and aortic stiffness after interleukin-6 receptor inhibition in rheumatoid arthritis. Atherosclerosis 2011, 219, 734-736. [CrossRef] [PubMed]

37. Luo, P.; Liu, Y.; Qiu, L.; Liu, X.; Liu, D.; Li, J. Tocilizumab treatment in COVID-19: A single center experience. J. Med. Virol. 2020, 92, 814-818. [CrossRef]

38. Landi, L.; Ravaglia, C.; Russo, E.; Cataleta, P.; Fusari, M.; Boschi, A.; Giannarelli, D.; Facondini, F.; Valentini, I.; Panzini, I.; et al. Blockage of interleukin-1 $\beta$ with canakinumab in patients with Covid-19. Sci. Rep. 2020, 10, 21775. [CrossRef] [PubMed]

39. Novartis' canakinumab failed to improve survival in COVID-19 study. Sci. Rep. 2020, 10. Available online: https://www.pmlive. com/pharma_news/novartis_canakinumab_failed_to_improve_survival_in_covid-19_study_1356209 (accessed on 22 January 2021).

40. European Medical Agency. Canakinumab Novartis. Available online: https://www.ema.europa.eu/en/documents/withdrawalreport/withdrawal-assessment-report-canakinumab-novartis_en.pdf (accessed on 22 January 2021).

41. Kooistra, E.J.; Waalders, N.J.B.; Grondman, I.; Janssen, N.A.F.; de Nooijer, A.H.; Netea, M.G.; van de Veerdonk, F.L.; Ewalds, E.; van der Hoeven, J.G.; Kox, M.; et al. Anakinra treatment in critically ill COVID-19 patients: A prospective cohort study. Crit Care 2020, 24, 688. [CrossRef]

42. Nosaka, N.; Martinon, D.; Moreira, D.; Crother, T.R.; Arditi, M.; Shimada, K. Autophagy protects against developing increased lung permeability and hypoxemia by down regulating inflammasome activity and IL-1 $\beta$ in LPS plus mechanical ventilationinduced acute lung injury. Front. Immunol. 2020, 11, 207. [CrossRef]

43. Hu, M.; Jia, F.; Huang, W.P.; Li, X.; Hu, D.F.; Wang, J.; Ren, K.F.; Fu, G.S.; Wang, Y.B.; Ji, J. Substrate stiffness differentially impacts autophagy of endothelial cells and smooth muscle cells. Bioact. Mater. 2020 6, 1413-1422. [CrossRef]

44. Rai, D.K.; Sharma, P.; Kumar, R. Post covid 19 pulmonary fibrosis-Is it reversible? Indian J. Tuberc. 2020. [CrossRef]

45. Santos, A.; Lagares, D. Matrix Stiffness: The Conductor of Organ Fibrosis. Curr. Rheumatol. Rep. 2018, 20. [CrossRef] [PubMed]

46. Lampi, M.C.; Reinhart-King, C.A. Targeting extracellular matrix stiffness to attenuate disease: From molecular mechanisms to clinical trials. Sci. Transl. Med. 2018, 10, eaao0475. [CrossRef] [PubMed]

47. Georges, P.C.; Hui, J.J.; Gombos, Z.; McCormick, M.E.; Wang, A.Y.; Uemura, M.; Mick, R.; Janmey, P.A.; Furth, E.E.; Wells, R.G. Increased stiffness of the rat liver precedes matrix deposition: Implications for fibrosis. Am. J. Physiol. Gastrointest. Liver. Physiol. 2007, 293, G1147-G1154. [CrossRef] [PubMed]

48. Liu, F.; Lagares, D.; Choi, K.M.; Stopfer, L.; Marinković, A.; Vrbanac, V.; Probst, C.K.; Hiemer, S.E.; Sisson, T.H.; Horowitz, J.C.; et al. Mechanosignaling through YAP and TAZ drives fibroblast activation and fibrosis. Am. J. Physiol. Lung Cell. Mol. Physiol. 2015, 308, L344-L357. [CrossRef]

49. Liu, F.; Mih, J.D.; Shea, B.S.; Kho, A.T.; Sharif, A.S.; Tager, A.M.; Tschumperlin, D.J. Feedback amplification of fibrosis through matrix stiffening and COX-2 suppression. J. Cell Biol. 2010, 190, 693-706. [CrossRef]

50. Jandl, K.; Kwapiszewska, G. Stiffness of the extracellular matrix: A regulator of prostaglandins in pulmonary fibrosis? Am. J. Respir. Cell Mol. Biol. 2020, 63, 721-722. [CrossRef]

51. Parker, M.W.; Rossi, D.; Peterson, M.; Smith, K.; Sikstrom, K.; White, E.S.; Connett, J.E.; Henke, C.A.; Larsson, O.; Peter, B.; et al. Fibrotic extracellular matrix activates a profibrotic positive feedback loop. J. Clin. Investig. 2014, 124, 1622-1635. [CrossRef]

52. Marinkovic, A.; Liu, F.; Tschumperlin, D.J. Matrices of physiologic stiffness potently inactivate idiopathic pulmonary fibrosis fibroblasts. Am. J. Respir. Cell Mol. Biol. 2013, 48, 422-430. [CrossRef] [PubMed]

53. Wigén, J.; Löfdahl, A.; Bjermer, L.; Elowsson-Rendin, L.; Westergren-Thorsson, G. Converging pathways in pulmonary fibrosis and Covid-19: The fibrotic link to disease severity. Respir. Med. X 2020, 2, 100023. [CrossRef] 
54. Sicard, D.; Haak, A.J.; Choi, K.M.; Craig, A.R.; Fredenburgh, L.E.; Tschumperlin, D.J. Aging and anatomical variations in lung tissue stiffness. Am. J. Physiol. Lung Cell. Mol. Physiol. 2018, 314, L946-L955. [CrossRef]

55. Aroor, A.R.; Jia, G.; Sowers, J.R. Cellular mechanisms underlying obesity-induced arterial stiffness. Am. J. Physiol. Regul. Integr. Comp. Physiol. 2018, 314, R387-R398. [CrossRef] [PubMed]

56. Gaetani, R.; Zizzi, E.A.; Deriu, M.A.; Morbiducci, U.; Pesce, M.; Messina, E. When stiffness matters: Mechanosensing in heart development and disease. Front. Cell Dev. Biol. 2020, 8, 334. [CrossRef] [PubMed]

57. Xu, J.; Xu, X.; Jiang, L.; Dua, K.; Hansbro, P.M.; Liu, G. SARS-CoV-2 induces transcriptional signatures in human lung epithelial cells that promote lung fibrosis. Respir. Res. 2020, 21, 182. [CrossRef]

58. Salamanna, F.; Maglio, M.; Landini, M.P.; Fini, M. Body localization of ACE-2: On the trail of the keyhole of SARS-CoV-2. Front. Med. 2020, 7, 594495. [CrossRef] [PubMed]

59. Baker, S.A.; Kwok, S.; Berry, G.J.; Montine, T.J. Angiotensin-converting enzyme 2 (ACE2) expression increases with age in patients requiring mechanical ventilation. MedRxiv 2020. [CrossRef]

60. Chen, J.; Jiang, Q.; Xia, X.; Liu, K.; Yu, Z.; Tao, W.; Gong, W.; Jing-Dong, J.; Han, J.J. Individual variation of the SARS-CoV-2 receptor ACE2 gene expression and regulation. Aging Cell 2020, 19, e13168. [CrossRef]

61. Yu, X.; Lin, Q.; Qin, X.; Ruan, Z.; Zhou, J.; Lin, Z.; Su, Y.; Zheng, J.; Li, Z. ACE2 antagonizes VEGFa to reduce vascular permeability during acute lung injury. Cell Physiol. Biochem. 2016, 38, 1055-1062. [CrossRef] [PubMed]

62. Chung, M.K.; Karnik, S.; Saef, J.; Bergmann, C.; Barnard, J.; Lederman, M.M.; Tilton, J.; Cheng, F.; Harding, C.V.; Young, J.B.; et al. SARS-CoV-2 and ACE2: The biology and clinical data settling the ARB and ACEI controversy. EbioMedicine 2020, $58,102907$. [CrossRef]

63. Mahmud, A.; Feely, J. Reduction in arterial stiffness with angiotensin II antagonist is comparable with and additive to ACE inhibition. Am. J. Hypertens. 2002, 15, 321-325. [CrossRef]

64. Liu, X.; Wang, Z.; Wang, P.; Yu, B.; Liu, Y.; Xue, Y. Green tea polyphenols alleviate early BBB damage during experimental focal cerebral ischemia through regulating tight junctions and PKCalpha signaling. BMC Complement. Altern. Med. 2013, 13, 187. [CrossRef]

65. Suzuki, T.; Hara, H. Role of flavonoids in intestinal tight junction regulation. J. Nutr. Biochem. 2011, 22, 401-408. [CrossRef]

66. Qi, Y.; Goel, R.; Kim, S.; Richards, E.M.; Carter, C.S.; Pepine, C.J.; Raizada, M.K.; Buford, T.W. Intestinal Permeability Biomarker Zonulin Is Elevated in Healthy Aging. J. Am. Med. Dir. Assoc. 2017, 18, 810.e1-810.e4. [CrossRef]

67. Bernardi, S.; Del Bo, C.; Marino, M.; Gargari, G.; Cherubini, A.; Andres-Lacueva, C.; Hidalgo-Liberona, N.; Peron, G.; lezDominguez, R.G.; Kroon, P.; et al. Polyphenols and Intestinal Permeability: Rationale and Future Perspectives. J. Agric. Food Chem. 2020, 68, 1816-1829. [CrossRef] [PubMed]

68. Grant, W.B.; Lahore, H.; McDonnell, S.L.; Baggerly, C.A.; French, C.B.; Aliano, J.L.; Bhattoa, H.P. Evidence that Vitamin D Supplementation Could Reduce Risk of Influenza and COVID-19 Infections and Deaths. Nutrients 2020, 12, 988. [CrossRef]

69. Mendonca, P.; Soliman, K.F.A. Flavonoids Activation of the Transcription Factor Nrf2 as a Hypothesis Approach for the Prevention and Modulation of SARS-CoV-2 Infection Severity. Antioxidants 2020, 9, 659. [CrossRef] [PubMed]

70. McCord, J.M.; Hybertson, B.M.; Cota-Gomez, A.; Geraci, K.P.; Gao, B. Nrf2 Activator PB125 ${ }^{\circledR}$ as a Potential Therapeutic Agent against COVID-19. Antioxidants 2020, 9, 518. [CrossRef] [PubMed]

71. Wen, Z.; Liu, W.; Li, X.; Chen, W.; Liu, Z.; Wen, J.; Liu, Z. A Protective Role of the NRF2-Keap1 Pathway in Maintaining Intestinal Barrier Function. Oxid. Med. Cell. Longev. 2019, 2019, 1759149. [CrossRef] [PubMed]

72. Aboonabi, A.; Singh, I. Chemopreventive role of anthocyanins in atherosclerosis via activation of Nrf2-ARE as an indicator and modulator of redox. Biomed. Pharmacother. 2016, 72, 30-36. [CrossRef] [PubMed]

73. Yu, J.S.; Chen, W.C.; Tseng, C.K.; Lin, C.K.; Hsu, Y.C.; Yen-Hsu Chen, Y.H.; Jin-Ching Lee, J.C. Sulforaphane Suppresses Hepatitis C Virus Replication by Up-Regulating Heme Oxygenase-1 Expression through PI3K/Nrf2 Pathway. PLoS ONE 2016, 11, e0152236. [CrossRef] [PubMed]

74. Hybertson, B.M.; Gao, B.; Bose, S.; McCord, J.M. Phytochemical Combination PB125 Activates the Nrf2 Pathway and Induces Cellular Protection against Oxidative Injury. Antioxidants 2019, 8, 119. [CrossRef]

75. Balogun, E.; Hoque, M.; Gong, P.; Killeen, E.; Green, C.J.; Foresti, R.; Alam, J.; Motterlini, R. Curcumin activates the haem oxygenase-1 gene via regulation of Nrf2 and the antioxidant-responsive element. Biochem. J. 2003, 371, 887-895. [CrossRef]

76. Liu, Z.; Dou, W.; Zheng, Y.; Wen, Q.; Qin, M.; Wang, X.; Tang, H.; Zhang, R.; Lv, D.; Wang, J.; et al. Curcumin upregulates Nrf2 nuclear translocation and protects rat hepatic stellate cells against oxidative stress. Mol. Med. Rep. 2016, 13, 1717-1724. [CrossRef]

77. Onodera, Y.; Teramura, T.; Takehara, T.; Fukuda, K. Hyaluronic acid regulates a key redox control factor Nrf2 via phosphorylation of Akt in bovine articular chondrocytes. FEBS Open Bio 2015, 5, 476-484. [CrossRef]

78. Ahmed, S.M.U.; Luo, L.; Namani, A.; Wang, X.J.; Tang, X. Nrf2 signaling pathway: Pivotal roles in inflammation. Biochim. Biophys. Acta Mol. Basis Dis. 2017, 1863, 585-597. [CrossRef]

79. Li, Z.; Gao, M.; Yang, B.; Zhang, H.; Wang, K.; Liu, Z.; Xiao, X.; Yang, M. Naringin Attenuates MLC Phosphorylation and NF-KB Activation to Protect Sepsis-Induced Intestinal Injury via RhoA/ROCK Pathway. Biomed. Pharmacother. 2018, 103, 50-58. [CrossRef] [PubMed]

80. DeDiego, M.L.; Nieto-Torres, J.L.; Regla-Nava, J.A.; Jimenez-Guardeño, J.M.; Fernandez-Delgado, R.; Fett, C.; Castaño-Rodriguez, C.; Perlman, S.; Enjuanes, L. Inhibition of NF-kB-mediated inflammation in severe acute respiratory syndrome coronavirus infected mice increase survival. J. Virol. 2014, 88, 915-924. [CrossRef] 
81. Horowitz, R.I.; Freeman, P.R.; Bruzzese, J. Efficacy of glutathione therapy in relieving dyspnea associated with COVID-19 pneumonia: A report of 2 cases. Respir. Med. Case Rep. 2020, 30, 101063. [CrossRef] [PubMed]

82. Angel, K.; Provan, S.A.; Gulseth, H.L.; Mowinckel, P.; Kvien, T.K.; Atar, D. Tumor Necrosis Factor- $\alpha$ Antagonists Improve Aortic Stiffness in Patients With Inflammatory Arthropathies. A Controlled Study. Hypertension 2010, 55, 333-338. [CrossRef] [PubMed]

83. Angel, K.; Provan, S.A.; Fagerhol, M.K.; Mowinckel, P.; Kvien, T.K.; Atar, D. Effect of 1-year anti-TNF- $\alpha$ therapy on aortic stiffness, carotid atherosclerosis, and calprotectin in inflammatory arthropathies: A controlled study. Am. J. Hypertens. 2012, 25, 644-650. [CrossRef]

84. Mäki-Petäjä, K.M.; Hall, F.C.; Booth, A.D.; Wallace, S.M.; Yasmin, B.A.; Bearcroft, P.W.; Harish, S.; Furlong, A.; McEniery, C.M.; Brown, J.; et al. Rheumatoid arthritis is associated with increased aortic pulse-wave velocity, which is reduced by anti-tumor necrosis factor-alpha therapy. Circulation 2006, 114, 1185-1192. [CrossRef]

85. Jacobsson, L.T.; Turesson, C.; Gulfe, A.; Kapetanovic, M.C.; Petersson, I.F.; Saxne, T.; Geborek, P. Treatment with tumor necrosis factor blockers is associated with a lower incidence of first cardiovascular events in patients with rheumatoid arthritis. J. Rheumatol. 2005, 32, 1213-1218.

86. Vlachopoulos, C.; Gravos, A.; Georgiopoulos, G.; Terentes-Printzios, D.; Ioakeimidis, N.; Vassilopoulos, D.; Stamatelopoulos, K.; Tousoulis, D. The effect of TNF-a antagonists on aortic stiffness and wave reflections: A meta-analysis. Clin. Rheumatol. 2018, 37, 515-526. [CrossRef]

87. Zanoli, L.; Granata, A.; Lentini, P.; Castellino, P.; Fatuzzo, P. The effect of tumor necrosis factor antagonists on functional aortic stiffening. Clin. Rheumatol. 2017, 36, 1927-1928. [CrossRef] [PubMed]

88. Barbaro, N.R.; de Araújo, T.M.; Tanus-Santos, J.E.; Anhê, G.F.; Fontana, V.; Moreno, H. Vascular Damage in Resistant Hypertension: TNF-Alpha Inhibition Effects on Endothelial Cells. BioMed Res. Int. 2015, 2015, 631594. [CrossRef]

89. Park, S.; Lakatta, E.G. Role of inflammation in the pathogenesis of arterial stiffness. Yonsei Med. J. 2012, 53, 258-261. [CrossRef]

90. Thevaranjan, N.; Puchta, A.; Schulz, C.; Naidoo, A.; Szamosi, J.C.; Verschoor, C.P.; Loukov, D.; Schenck, L.P.; Jury, J.; Foley, K.P.; et al. Age-Associated Microbial Dysbiosis Promotes Intestinal Permeability, Systemic Inflammation, and Macrophage Dysfunction. Cell Host Microbe 2017, 21, 455-466. [CrossRef]

91. Giron, L.B.; Dweep, H.; Yin, X.; Wang, H.; Damra, M.; Goldman, A.R.; Gorman, N.; Palmer, C.S.; Tang, H.Y.; Shaikh, M.W.; et al. Severe COVID-19 Is Fueled by Disrupted Gut Barrier Integrity. MedRxiv 2020. [CrossRef]

92. Liu, G.H.; Qu, J.; Shen, X. NF-kB/p65 antagonizes Nrf2-ARE pathway by depriving CBP from Nrf2 and facilitating recruitment of HDAC3 to MafK. Biochim. Biophys. Acta Mol. Cell Res. 2008, 1783, 713-727. [CrossRef]

93. Cuadrado, A.; Pajares, M.; Benito, C.; Jiménez-Villegas, J.; Escoll, M.; Fernández-Ginés, R.; Garcia Yagüe, A.J.; Lastra, D.; Manda, G.; Rojo, A.I.; et al. Can Activation of NRF2 Be a Strategy against COVID-19? Trends Pharmacol. Sci. 2020, 41, 598-610. [CrossRef]

94. Lin, W.; Wu, R.T.; Wu, T.; Khor, T.O.; Wang, H.; Kong, A.N. Sulforaphane suppressed LPS-induced inflammation in mouse peritoneal macrophages through Nrf2 dependent pathway. Biochem. Pharmacol. 2008, 76, 967-973. [CrossRef]

95. Wardyn, J.D.; Ponsford, A.H.; Sanderson, C.M. Dissecting molecular cross-talk between Nrf2 and NF- $\mathrm{B}$ response pathways. Biochem. Soc. Trans. 2015, 43, 621-626. [CrossRef]

96. Yang, H.; Cheam, N.M.J.; Cao, H.; Lee, M.K.H.; Sze, S.K.; Tan, N.S.; Tay, C.Y. Materials Stiffness-Dependent Redox Metabolic Reprogramming of Mesenchymal Stem Cells for Secretome-Based Therapeutic Angiogenesis. Adv. Healthc. Mater. 2019, 8 , 1900929. [CrossRef] [PubMed]

97. Zak-Golab, A.; Kocelak, P.; Aptekorz, M.; Zientara, M.; Juszczyk, L.; Martirosian, G.; Chudek, J.; Olszanecka-Glinianowicz, M. Gut Microbiota, Microinflammation, Metabolic Profile, and Zonulin Concentration in Obese and Normal Weight Subjects. Int. J. Endocrinol. 2013, 2013, 674106. [CrossRef]

98. Seo, B.R.; Bhardwaj, P.; Choi, S.; Gonzalez, J.; Anresen Eguiluz, R.C.; Wang, K.; Mohanan, S.; Morris, P.G.; Du, B.; Zhou, X.K.; et al. Obesity-dependent changes in interstitial ECM mechanics promote breast tumorigenesis. Sci. Transl. Med. 2015, 7, 301ra130. [CrossRef] [PubMed]

99. Martinon, D.; Borges, V.F.; Gomez, A.C.; Shimada, K. Potential Fast COVID-19 Containment With Trehalose. Front. Immunol. 2020, 11, 1623. [CrossRef] [PubMed]

100. Sarkar, S.; Davies, J.E.; Huang, Z.; Tunnacliffe, A.; Rubinsztein, D.C. Trehalose, a novel mTOR-independent autophagy enhancer, accelerates the clearance of mutant huntingtin and alpha-synuclein. J. Biol. Chem. 2007, 282, 5641-5652. [CrossRef]

101. Taya, K.; Hirose, K.; Hamada, S. Trehalose inhibits inflammatory cytokine production by protecting IkappaB-alpha reduction in mouse peritoneal macrophages. Arch. Oral Biol. 2009, 54, 749-756. [CrossRef]

102. Yaribeygi, H.; Yaribeygi, A.; Sathyapalan, T.; Sahebkar, A. Molecular mechanisms of trehalose in modulating glucose homeostasis in diabetes. Diabetes Metab. Syndr. 2019, 13, 2214-2218. [CrossRef]

103. Nazari-Robati, M.; Akbari, M.; Khaksari, M.; Mirzaee, M. Trehalose attenuates spinal cord injury through the regulation of oxidative stress, inflammation and GFAP expression in rats. J. Spinal Cord Med. 2019, 42, 387-394. [CrossRef]

104. Hooper, P.L. COVID-19 and heme oxygenase: Novel insight into the disease and potential therapies. Cell Stress Chaperones 2020, 25, 707-710. [CrossRef]

105. Radenkovic, D.; Chawla, S.; Pirro, M.; Sahebkar, A.; Banach, M. Cholesterol in relation to COVID-19: Should we care about it? J. Clin. Med. 2020, 9, 1909. [CrossRef] [PubMed]

106. Lu, Y.; Liu, D.X.; Tam, J.P. Lipid rafts are involved in SARS-CoV entry into vero E6 cells. Biochem. Biophys. Res. Commun. 2008, 369, 344-349. [CrossRef] [PubMed] 
107. Seifalian, A.M.; Filippatos, T.D.; Joshi, J.; Mikhailidis, D.P. Obesity and arterial compliance alterations. Curr. Vasc. Pharmacol. 2010, 8, 155-168. [CrossRef]

108. Wang, H.; Yuan, Z.; Pavel, M.A.; Hobson, R.; Hansen, S.B. The role of high cholesterol in age-related COVID19 lethality. BioRxiv 2020. [CrossRef]

109. Wang, S.; Li, W.; Hui, H.; Tiwari, S.K.; Zhang, Q.; Croker, B.A.; Rawlings, S.; Smith, D.; Carlin, A.F.; Rana, T.M. Cholesterol 25-Hydroxylase inhibits SARS-CoV-2 and other coronaviruses by depleting membrane cholesterol. EMBO J. 2020, 39 , e106057. [CrossRef]

110. Lampi, M.C.; Faber, C.J.; Huynh, J.; Bordeleau, F.; Zanotelli, M.R.; Reinhart-King, C.A. Simvastatin ameliorates matrix stiffnessmediated endothelial monolayer disruption. PLoS ONE 2016, 11, e0147033. [CrossRef]

111. Bifulco, M.; Gazzerro, P. Statins in coronavirus outbreak: It's time for experimental and clinical studies. Pharmacol. Res. 2020, 156, 104803. [CrossRef]

112. Mehrbod, P.; Omar, A.R.; Hair-Bejo, M.; Haghani, A.; Ideris, A. Mechanisms of action and efficacy of statins against influenza. Biomed. Res. Int. 2014, 2014, 872370. [CrossRef]

113. Chiu, C.Y.; Yen, T.E.; Liu, S.H.; Chiang, M.T. Comparative effects and mechanisms of chitosan and its derivatives on hypercholesterolemia in high-fat diet-fed rats. Int. J. Mol. Sci. 2020, 21, 92. [CrossRef] [PubMed]

114. Harisa, G.I.; Attia, S.M.; Zoheir, K.M.; Alanazi, F.K. Chitosan treatment abrogates hypercholesterolemia-induced erythrocyte's arginase activation. Saudi Pharm. J. 2017, 25, 120-127. [CrossRef] [PubMed]

115. Rakcejeva, T.; Rusa, K.; Dukalska, L.; Kerch, G. Effect of chitosan and chitooligosaccharide lactate on free lipids and reducing sugars content and on wheat bread firming. Eur. Food Res. Technol. 2011, 232, 123-128. [CrossRef] 